\section{Comparing the immunogenicity of the etanercept biosimilar SB4 with the innovator etanercept: another consideration}

In their 2015 publication, Emery et $a l^{1}$ reported findings of a phase III, randomised, double-blind study comparing the investigational etanercept biosimilar SB4 (Samsung Bioepis, Incheon, Korea) with the innovator etanercept in patients who have moderate-to-severe rheumatoid arthritis (RA) despite methotrexate treatment. Although the authors reported equivalent clinical efficacy between the SB4 and reference product, they found a significantly lower incidence of antidrug antibodies (ADAs) against SB4 than against etanercept, that is, $2(0.7 \%)$ patients in the SB4 group and 39 (13.1\%) patients in the etanercept group were ADA positive by week $24(\mathrm{p}<0.001)$. We acknowledge the two recently published Letters to the Editor of the Annals of the Rheumatic Diseases by Moots et $a l^{2}$ and a response by Emery et $a l,{ }^{3}$ in which important aspects of these immunogenicity results were discussed, and would also like to offer an additional consideration.

The etanercept immunogenicity findings reported in the original manuscript ${ }^{1}$ warrant closer inspection, as they are inconsistent with those reported in previously published clinical studies ${ }^{4-10}$ and the European and the US product labelling for the reference product, etanercept, ${ }^{11} 12$ which establish ADA rates in etanercepttreated patients to be $0 \%-6 \%$ in patients with RA, with no reported cases of neutralising ADAs. Importantly, the ADA results and conclusions in the Emery et $a l^{1}$ publication also are inconsistent with those presented in the European Medicines Agency's (EMA) Committee for Medicinal Products for Human Use (CHMP) European Public Assessment Report (EPAR) for SB4, which was published on the EMA website on 28 January $2016 .^{13}$ When assessing the SB4 marketing application, the CHMP determined that the immunogenicity findings of this study were 'uncertain because of the low drug tolerance of the ADA assay that led to a low sensitivity and a potential bias'. ${ }^{13}$ Specifically, the drug tolerance level of the ADA assay was close to mean trough levels, and SB4 trough levels were slightly higher at weeks 4 and 8 , when most of the etanercept ADA-positive samples were obtained. A reanalysis of the ADA prevalence by treatment arm excluding samples obtained at weeks 4 and 8 was subsequently submitted. After this adjustment, no significant difference was seen in overall incidence of ADAs between the SB4 (0/299 (0\%)) and etanercept $(2 / 296(0.7 \%) ; p=0.247)$ groups at week 24 . Thus, the CHMP stated that 'SB4 is not more immunogenic than Enbrel' (etanercept) and that 'based on the current knowledge of the low drug tolerance of the ADA assay and the possibility of more falsenegative results in the SB4 arm, it is premature to conclude that SB4 is less immunogenic than Enbrel'. ${ }^{13}$

In the Emery et $a l^{3}$ response to Moots et $a l,{ }^{2}$ the authors claim that 'standard reporting procedures' were followed when presenting the ADA data, citing the American Association of Pharmaceutical Scientists recommendations for assessment of product immunogenicity published by Shankar et al. ${ }^{14}$ The latter authors proposed harmonised terminology and recommendations for reporting immunogenicity data because standard reporting procedures do not exist across the industry. Shankar et al explicitly recommended that researchers identify samples containing drug concentrations that can interfere with ADA assays as 'inconclusive', a recommendation that was not followed in the original ADA analyses of the SB4 study. ${ }^{1}$

Comprehensive and detailed information about new study methodology and findings is urgently needed to ensure well- informed decision making by clinicians, patients and payers. We acknowledge that Emery et $a l^{3}$ consider their study's immunogenicity data to be 'valid and reliable'. However, based on the conclusion stated in the EPAR that the ADA assay 'suffers from a low drug tolerance that renders the ADA results of the Study SB4-G31-RA somewhat uncertain' and the contradictory findings obtained following reanalysis of the data, ${ }^{13}$ we respectfully disagree. We believe the readership of the Annals of the Rheumatic Diseases should be made aware of the discrepancy between the data published in the study by Emery et $a l^{1}$ and those presented in the $\mathrm{EPAR}^{13}$ regarding ADA incidence in patients with RA treated with SB4 and etanercept. Moreover, as the science of immunogenicity of biological therapeutics is complex and still evolving, we hope that this discrepancy will provide muchneeded impetus for researchers, journal editors and reviewers to increase their scrutiny of ADA analyses in the future. Closer inspection of immunogenicity methodology and findings will help to avoid drawing conclusions based on a single descriptor of incidence, which in this case were inconsistent with regulators' conclusions drawn from a thorough analysis of all the data.

\section{Lisa Marshall, ${ }^{1}$ Timothy Hickling, ${ }^{2}$ David Bill, ${ }^{3}$ Ehab Mahgoub ${ }^{1}$}

${ }^{1}$ Pfizer, Collegeville, Pennsylvania, USA

${ }^{2}$ Pfizer, Andover, Massachusetts, USA

${ }^{3}$ Pfizer UK, Surrey, UK

Correspondence to Lisa Marshall, Pfizer, 500 Arcola Rd, Collegeville, PA 19426, USA; Lisa.Marshall2@pfizer.com

Contributors All authors were involved in drafting the Letter and revising it critically for important intellectual content, and all authors approved the final version to be published. Editorial/medical writing support was provided by Donna McGuire of Engage Scientific Solutions and was funded by Pfizer.

Funding Editorial/medical writing support was provided by Donna McGuire of Engage Scientific Solutions and was funded by Pfizer.

Competing interests Authors are employees of Pfizer.

Provenance and peer review Not commissioned; internally peer reviewed.

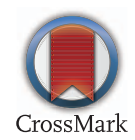

To cite Marshall L, Hickling T, Bill D, et al. Ann Rheum Dis 2016;75:e37.

Received 7 March 2016

Accepted 8 March 2016

Published Online First 31 March 2016

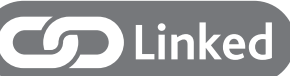

- http://dx.doi.org/10.1136/annrheumdis-2016-209517

Ann Rheum Dis 2016;75:e37. doi:10.1136/annrheumdis-2016-209502

\section{REFERENCES}

1 Emery P, Vencovsky J, Sylwestrzak A, et al. A phase III randomised, double-blind, parallel-group study comparing SB4 with etanercept reference product in patients with active rheumatoid arthritis despite methotrexate therapy. Ann Rheum Dis 2015; Published Online First 6 Jul 2015. doi:10.1136/annrheumdis-2015-207588

2 Moots RJ, Balsa A, Wolbink G. Reporting of potential immunogenicity with biologic drugs: clarity and accuracy required. Ann Rheum Dis 2016;75:e24.

3 Emery P, Vencovsky J, Ghil J. Response to: 'Reporting of potential immunogenicity with biologic drugs: clarity and accuracy required' by Moots et al. Ann Rheum Dis 2016;75:e25.

4 Dore RK, Mathews S, Schechtman J, et al. The immunogenicity, safety, and efficacy of etanercept liquid administered once weekly in patients with rheumatoid arthritis. Clin Exp Rheumatol 2007;25:40-6.

5 Klareskog L, Gaubitz M, Rodríguez-Valverde V, et al. Assessment of long-term safety and efficacy of etanercept in a 5-year extension study in patients with rheumatoid arthritis. Clin Exp Rheumatol 2011;29:238-47. 
6 Hoshino M, Yoshio T, Onishi $\mathrm{S}$, et al. Influence of antibodies against infliximab and etanercept on the treatment effectiveness of these agents in Japanese patients with rheumatoid arthritis. Mod Rheumatol 2012;22:532-40.

7 Daïen $\mathrm{Cl}$, Daïen $\mathrm{V}$, Parussini $\mathrm{E}$, et al. Etanercept concentration in patients with rheumatoid arthritis and its potential influence on treatment decisions: a pilot study. J Rheumatol 2012;39:1533-8.

8 Jamnitski A, Krieckaert CL, Nurmohamed MT, et al. Patients non-responding to etanercept obtain lower etanercept concentrations compared with responding patients. Ann Rheum Dis 2012;71:88-91.

9 Jani $\mathrm{M}$, Chinoy $\mathrm{H}$, Warren RB, et al. Clinical utility of random anti-tumour necrosis factor drug testing and measurement of anti-drug antibodies on long-term treatment response in rheumatoid arthritis. Lancet 2015; 385(Suppl 1):S48.

10 Krieckaert CL, Jamnitski A, Nurmohamed MT, et al. Comparison of long-term clinical outcome with etanercept treatment and adalimumab treatment of rheumatoid arthritis with respect to immunogenicity. Arthritis Rheum 2012:64:3850-5.

11 European Medicines Agency. Enbrel (etanercept) Summary of Product Characteristics. http://www.ema.europa.eu/docs/en_GB/document_library/EPAR_Product_Information/human/000262/WC500027361.pdf (accessed 1 Mar 2016).

12 Amgen. Enbrel (etanercept) solution for subcutaneous use: US prescribing information. 2013. http://pi.amgen.com/united_states/enbrel/derm/enbrel_pi.pdf (accessed 1 Mar 2016).

13 Committee for Medicinal Products for Human Use of the European Medicines Agency. Benepali: assessment report. 2015. http://www.ema.europa.eu/docs/en_GB/ document_library/EPAR_-_Public_assessment_report/human/004007/ WC500200380.pdf (accessed 1 Mar 2016).

14 Shankar G, Arkin S, Cocea L, et al. Assessment and reporting of the clinical immunogenicity of therapeutic proteins and peptides-harmonized terminology and tactical recommendations. AAPS J 2014;16:658-73. 